\title{
Benthic diatoms and some environmental conditions in three lowland streams
}

\author{
M. Licursi ${ }^{1}$ \\ N. Gómez 1
}

Keywords : benthic diatoms, tolerance spectrums, lowland streams, Argentina.

This article reports on the ecological preferences of benthic diatoms in relation to $\mathrm{pH}$, conductivity and organic pollutioneutrophication and their tolerance spectrums. Three Pampean streams subjected to different human impacts were studied. The bottom substrate of these streams is mostly composed of slime-clay with low proportions of gravel and sand ; in consequence, the epipelon is the most represented benthic community. Samples were taken seasonally between 1997-1998 at 9 sampling sites. In each sampling station ten sub-samples were collected by pipetting a superficial layer $(5-10 \mathrm{~mm})$ of sediment from different places. Physico-chemical parameters were measured. Considering the ranges of $\mathrm{pH}$, conductivity and organic pollution-eutrophication the diatom's tolerance spectrums were established. 162 diatom species were identified. More than $50 \%$ of species occurred in sites where the conductivity was lower than $600 \mu \mathrm{S} \mathrm{cm}^{-1}$. More than $50 \%$ of species had their preference range in sites with moderate organic matter and nutrient content. Diatom species found show defined preferences for organic pollutioneutrophication, but show less consistent responses for conductivity and, particularly, hydrogen ions content.

\section{Diatomées benthiques de trois fleuves de plaine et leur répartition en fonction des conditions de milieu}

Mots-clés : diatomées benthiques, spectre de tolérance, fleuves de plaine, Argentine.

L'objet de cet article est d'exposer les préférences écologiques des diatomées benthiques en fonction du pH, de la conductivité, du degré d'eutrophisation et de la pollution organique afin de définir leurs spectres de tolérance. Trois fleuves de la Pampa soumis à différentes influences humaines ont été choisis.

Le substrat de ces fleuves est le plus souvent constitué par de l'argile limoneuse avec une faible proportion de gravier et de sable ; par suite, la communauté benthique est surtout représentée par l'épipélon. Des échantillons ont été prélevés dans 9 stations de 1997 à 1998 en fonction des saisons. A chaque station, 10 sous-échantillons étaient récoltés en pipetant la couche superficielle $(5-10 \mathrm{~mm})$ de sédiment en différents endroits. Les principaux paramètres physico-chimiques ont été mesurés. Le spectre de tolérance des espèces a été défini en fonction du $\mathrm{pH}$, de la conductivité et du degré d'eutrophisation et de pollution organique. 162 espèces de diatomées ont été identifiées. Plus de $50 \%$ des espèces ont été rencontrées dans les stations où la conductivité était inférieure à $600 \mu \mathrm{S} \mathrm{cm}^{-1}$. Plus de $50 \%$ des espèces montrent une préférence pour les stations où les teneurs en matière organique et en nutriments sont modérées. Les espèces rencontrées se répartissent en fonction du degré de pollution organique et d'eutrophisation. Par contre, il n'y a pas de répartition nette des espèces en fonction de la conductivité et du pH. 


\section{Introduction}

Diatoms are valuable indicators of environmental conditions in rivers and streams, because they respond directly and sensitively to many physical, chemical, and biological changes in river and stream ecosystems such as temperature, light, flow, nutrient, conductivity, organic and inorganic pollution, acidification and grazing (Patrick \& Reimer 1966, 1975, Lowe 1974, Schoeman 1976, Lange-Bertalot 1979, Gasse 1986, Steinberg \& Schiefele 1988, Sabater \& Roca 1990, Descy \& Coste 1990, Steinberg \& Putz 1991, Van Dam et al. 1994, Krno 1998, Stevenson \& Pan 1999, Anderson et al. 1999, Forrester et al. 1999, Pan et al. 2000). Species autoecology is the basis of the composition and distribution of the diatom assemblages (Sabater \& Sabater 1988, Wilderman 1984).

Lotic systems traversing the NE of Pampean plain are affected by the activities and products of agriculture, cattle-raising, and industry. In addition, the most important urban centre in Argentina is located in this area. Water quality deterioration is mostly caused by organic enrichment, nutrients' input, heavy metals, pathogenic agents, pesticides and herbicides.

The bottom substrate is mostly composed of slimeclay with low proportions of gravel and sand, except at the mouth of the rivers and streams where sand can be dominant. Limestone concretions can be found in mid or lower sections of certain streams (Gómez \& Licursi 2001). In consequence, the epipelon is the most represented benthic community in these running waters.

Gómez (1998, 1999) and Tangorra et al. (1998) described the diatom assemblages, found in epipelon of Matanza-Riachuelo basin and El Gato stream, and their relationship with water quality. Gómez \& Licursi (2001) have developed an index (IDP- Diatom Pampean Index) which is based on the sensitivity of the epipelic diatom assemblages integrating the effect of organic enrichment and eutrophication.

The purpose of this article is to expose the ecological preferences of benthic diatoms in relation with $\mathrm{pH}$, conductivity and organic pollution-eutrophication and obtain their tolerance spectrums. For this purpose three Pampean streams subjected to different human impacts were selected.

\section{Material and methods}

\section{- Study area}

Three pampean plain streams were selected in La Plata surroundings (Buenos Aires province, Argenti- ne) (Fig. 1). These systems are subjected to different human-impacts.

The Rodríguez stream, $22 \mathrm{~km}$ long, runs across suburban areas exposed to permanent contamination. The upstream section is subjected to agriculture and cattle farming, in its medium section there are also the effluents of a meat factory, and downstream the most important impact is due to urban activities (sewage discharge insufficiently treated).

In El Pescado stream, $36 \mathrm{~km}$ long, agriculture and cattle farming are the main activities in the basin.

The El Gato stream runs across an urban and industrialised area along its $21 \mathrm{~km}$. Its contamination is a complex of industrial effluents discharge (metallurgical, siderurgical and chemical ones, paper industry) without previous adequate treatment, agrochemical compounds, and sewage discharge insufficiently treated.

The studied streams lack autochthonous riparian vegetation ; in headwaters there are few hydrophytes, but they are abundantly developed downstream. The most frequent species are Sagittaria montevidensis Cham. and Schl., Roripa nasturtium-aquaticum (L.) Hayek, Hidrocleis nymphoides (Wild.) Buchenau, Alternanthera filoxeroides (Mart.) Griseb., Hydrocotyle bonariensis Lam. and Polygonum punctatum Elliot.

\section{- Sampling collection}

The samples were taken seasonally between 1997-1998 at 9 sampling sites distributed in Rodríguez, El Pescado and El Gato streams (Fig. 1). In each sampling station ten sub-samples were collected by pipetting (Stevenson 1984, Lowe \& Laliberte 1996) a superficial layer $(5-10 \mathrm{~mm})$ of sediment from different places, following Descy \& Coste (1990) recommendations. Samples were fixed in $4 \%$ formalin. The organic matter was oxidised with hydrogen peroxide. Clean diatoms were mounted in Naphrax ${ }^{\circledR}$, counting up to 300 valves in each sample with an optical microscope BH Olympus with phase contrast, assessing the relative abundance of each identified taxa. Diatoms were determined according to : Hustedt (1930), Patrick \& Reimer (1966, 1975), Krammer \& Lange-Bertalot (1986, 1988, 1991a, \& b) and Cox (1996).

\section{- Water analysis}

Temperature, dissolved oxygen, conductivity, $\mathrm{pH}$, turbidity and flow were measured with portable meters. Water samples for the dissolved inorganic nutrients analysis were filtered immediately through glass fibber filters (Whatman GF/C) and together with samples for $\mathrm{BOD}_{5}$ and $\mathrm{COD}$ were stored at $4^{\circ} \mathrm{C}$ until arrival to the laboratory. Soluble reactive phospho- 
Table 1. Average, maximum and minimum (in brackets) values of physical and chemical characteristics of streams studied. Tableau 1. Moyennes, maximums et minimums (entre parenthèses) des valeurs des paramètres physico-chimiques étudiés.

\begin{tabular}{|c|c|c|c|c|c|c|c|c|c|}
\hline & $\begin{array}{c}\mathrm{DO} \\
\mathrm{mg} \mathrm{l}^{-1}\end{array}$ & $\begin{array}{l}\text { Conductivity } \\
\mu \mathrm{S} \mathrm{cm} \mathrm{cm}^{-1}\end{array}$ & $\begin{array}{l}\mathrm{COD} \\
\mathrm{mg} \mathrm{l}^{-1}\end{array}$ & $\begin{array}{l}\mathrm{BOD}_{5} \\
\mathrm{mg} \mathrm{l}^{-1}\end{array}$ & $\begin{array}{c}\text { PRS } \\
\text { mg P Pl }^{-1}\end{array}$ & $\begin{array}{c}\mathrm{NH}_{4}^{+} \\
\mathrm{mg} \mathrm{Nl}^{-1}\end{array}$ & $\begin{array}{c}\mathrm{NO}_{2}^{-} \\
\mathrm{mg} \mathrm{N} l^{-1}\end{array}$ & $\begin{array}{c}\mathrm{NO}_{3}^{-} \\
\mathrm{mg} \mathrm{N}\end{array}$ & $\mathrm{pH}$ \\
\hline Rodriguez & $\begin{array}{c}5.7 \\
(9.8-2.7)\end{array}$ & $\begin{array}{c}947.2 \\
(1593.0-299.0)\end{array}$ & $\begin{array}{c}37.9 \\
(104.0-10.6)\end{array}$ & $\begin{array}{c}15.6 \\
(34.0-3.0)\end{array}$ & $\begin{array}{c}7.4 \\
(58.3-0.3)\end{array}$ & $\begin{array}{c}15.05 \\
(45.90-0.05)\end{array}$ & $\begin{array}{c}0.45 \\
(0.87-0.02)\end{array}$ & $\begin{array}{c}3.76 \\
(21.82-0.04)\end{array}$ & $\begin{array}{c}7.8 \\
(9.1-7.0)\end{array}$ \\
\hline El Gato & $\begin{array}{c}3.4 \\
(10.0-0.2)\end{array}$ & $\begin{array}{c}967.6 \\
(1354.0-476.0)\end{array}$ & $\begin{array}{c}42.8 \\
(142.0-12.0)\end{array}$ & $\begin{array}{c}13.7 \\
(28.0-4.0)\end{array}$ & $\begin{array}{c}1.8 \\
(4.2-0.3)\end{array}$ & $\begin{array}{c}6.76 \\
(16.18-1.14)\end{array}$ & $\begin{array}{c}0.22 \\
(0.78-0.02)\end{array}$ & $\begin{array}{c}1.53 \\
(6.31-0.16)\end{array}$ & $\begin{array}{c}8.1 \\
(9.2-7.1)\end{array}$ \\
\hline El Pescado & $\begin{array}{c}6.3 \\
(8.3-4.3)\end{array}$ & $\begin{array}{c}401.6 \\
(713.0-171.0)\end{array}$ & $\begin{array}{c}41.4 \\
(109.0-4.0)\end{array}$ & $\begin{array}{c}9.6 \\
(21.0-2.0)\end{array}$ & $\begin{array}{c}0.4 \\
(1.1-0.1)\end{array}$ & $\begin{array}{c}0.37 \\
(0.95-0.06)\end{array}$ & $\begin{array}{c}0.03 \\
(0.09-0.01)\end{array}$ & $\begin{array}{c}0.29 \\
(0.84-0.02)\end{array}$ & $\begin{array}{c}8.3 \\
(9.3-7.0)\end{array}$ \\
\hline
\end{tabular}

rus, nitrite and ammoniacal nitrogen, sulphate, carbonate, bicarbonate, chloride, calcium, magnesium, sodium, potassium, $\mathrm{BOD}_{5}$ and $\mathrm{COD}$ were determined following standard procedures (Mackereth et al. 1978, Tabatabai 1974, APHA 1998). The ionic composition was represented according to Maucha (1932).

\section{- Spectrums}

The ranges selected for $\mathrm{pH}$, conductivity and organic pollution-eutrophication and showed in Table 1,2 and 3. According to Gómez \& Licursi (2001), $\mathrm{BOD}_{5}, \mathrm{PO}_{4}$ and $\mathrm{NH}_{4}{ }^{+}$showed a close relationship with organic pollution and eutrophication and are considered as use-

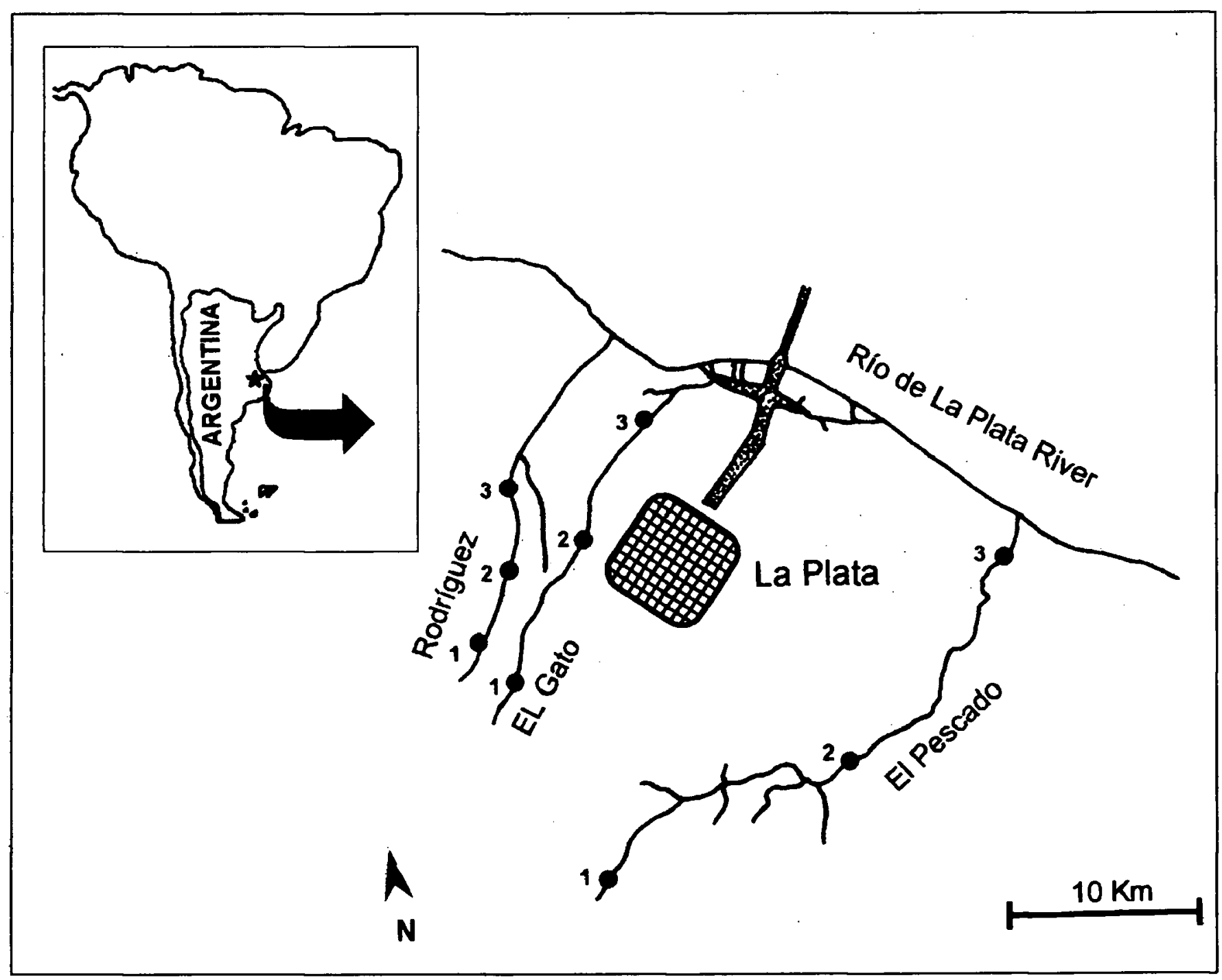

Fig. 1. Map showing the streams studied and location of sampling sites.

Fig. 1. Localisation des fleuves et des stations de prélèvements. 
ful indicators of these phenomena in the Pampean streams. Using this information diatom's tolerance spectrums were established including only species with a relative frequency greater than or equal to $1 \%$ in three samples and $5 \%$ at least in one sample.

\section{- Statistical methods}

Pearson's correlation analysis and multiple correlations were used in order to explore the relation among relative abundant species with variables chosen for the spectrums (Sokal \& Rohlf 1969).

\section{- Granulometric methods}

The gravel and sand fraction was determined with sieves ; the Stoke's principle was applied for clay and slime fraction (Depetris 1995).

\section{Results}

\subsection{Water quality}

The ionic water composition, in the streams analysed, is sodium-carbonated. In El Gato and Rodríguez streams the $\mathrm{Na}^{+}, \mathrm{K}^{+}, \mathrm{Mg}^{++}, \mathrm{Cl}^{-}, \mathrm{CO}_{3}=, \mathrm{HCO}_{3}^{-}$amount is higher than in El Pescado stream (Fig. 2). Conductivity, $\mathrm{BOD}_{5}, \mathrm{PRS}, \mathrm{NH}_{4}{ }^{+}, \mathrm{NO}_{3}{ }^{-}, \mathrm{NO}_{2}=$ average amounts increase in $\mathrm{El}$ Gato and Rodríguez stream while DO decreases (Table 1).

These streams can be enriched by organic matter or minerals, natural means (El Pescado stream), and/or contamination (El Gato and Rodríguez streams). In El Pescado stream the high organic matter concentration coming from macrophyte detritus and humic compounds can increase the COD values.

\subsection{Bottom}

The analysis of granulometric composition from these streams shows sediments dominance with a diameter $62-425 \mu \mathrm{m}$ ( $44 \%$ of the samples). In $33 \%$ of the samples the sediments are bigger than $425 \mu \mathrm{m}$ and in the rest of the samples $(23 \%)$ the sediments are smaller than $62 \mu \mathrm{m}$.

\subsection{Ecological preferences}

A total of 162 diatom species were identified : 91 in Rodríguez stream, 43 in El Gato stream and 143 in El Pescado stream.

According to the established criterion for the selection 32 species were included in tolerance spectrums. More than $50 \%$ of species were found in sites where the conductivity was lower than $600 \mu \mathrm{S} \mathrm{cm}^{-1}$. Only the $16 \%$ of species were indifferent to the conductivity (Fig. 3a). The Pearson coefficients $(p<0.05)$ showed that Cocconeis placentula, Nitzschia amphibia, Ach-
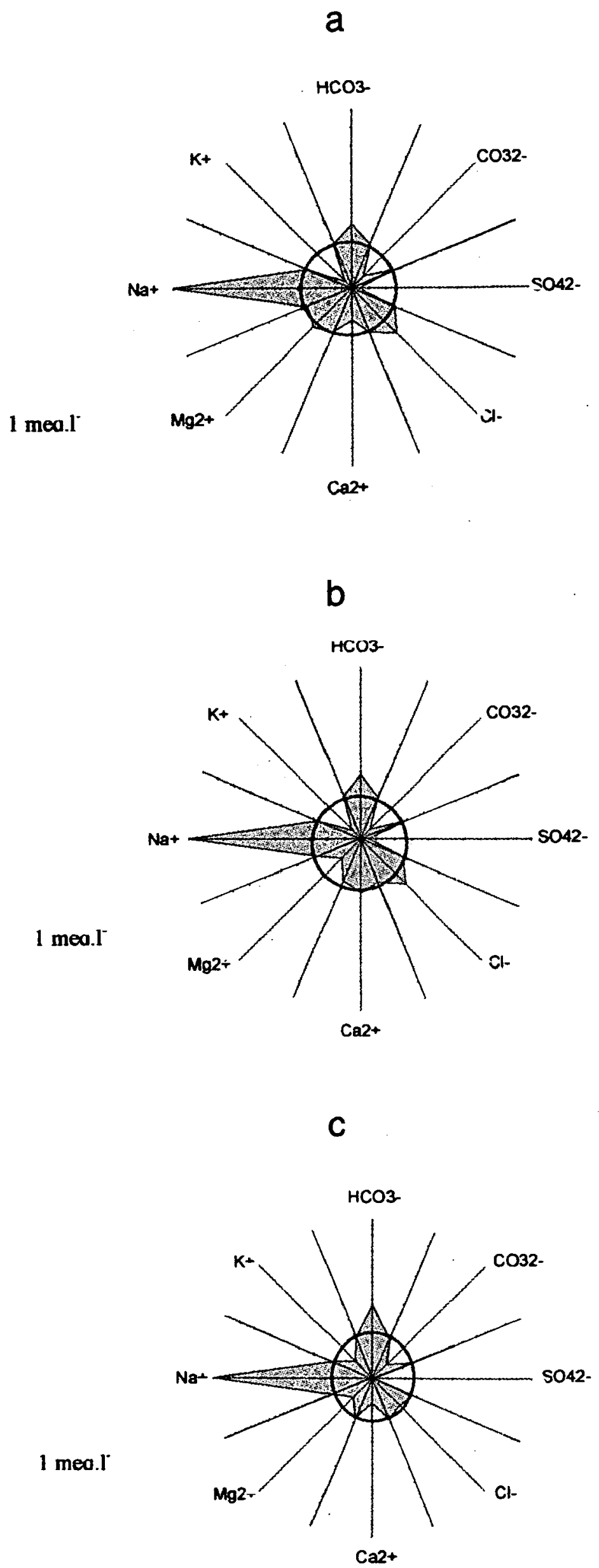

Fig. 2. Ionic composition of : a) El Gato stream ; b) El Pescado stream ; c) Rodríguez stream.

Fig. 2. Spectre de la composition ionique des 3 fleuves : a) El Gato ; b) El Pescado ; c) Rodriguez. 


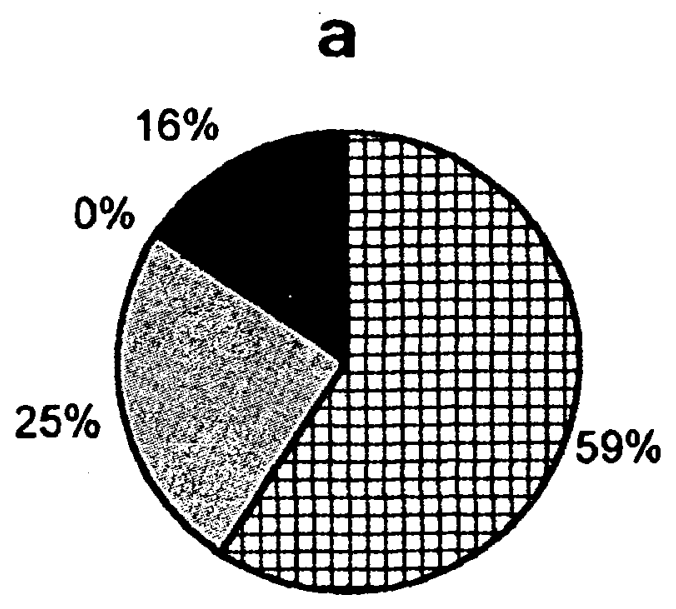

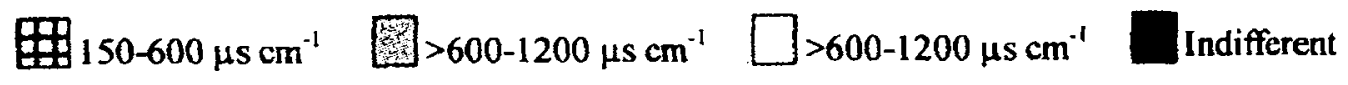

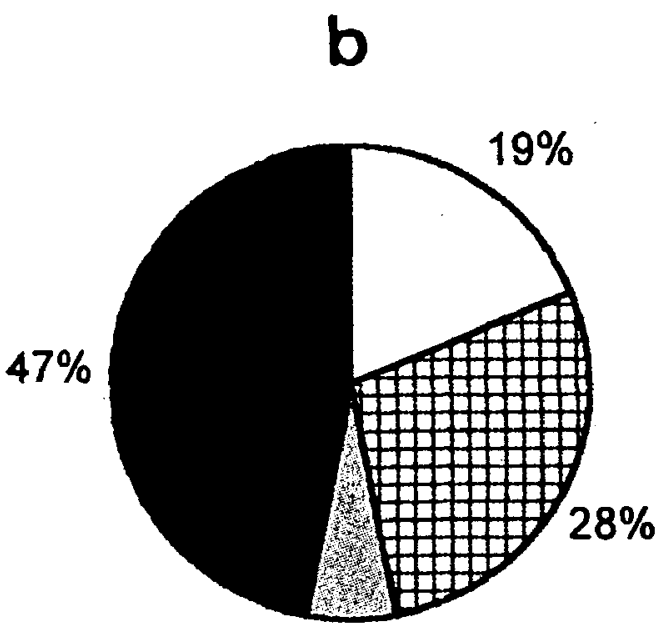

$6 \%$

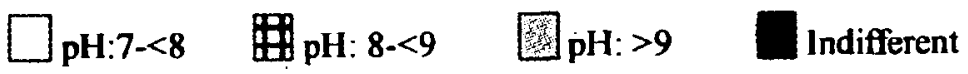

C

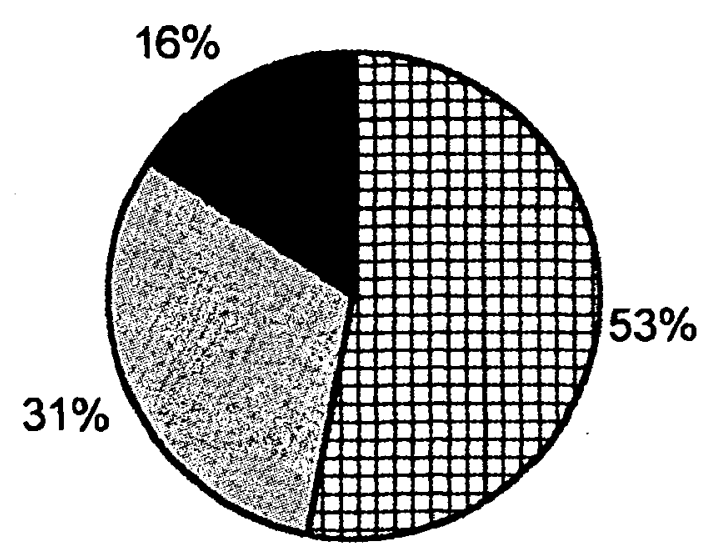

BOD $31.5-<15 \mathrm{NH}_{4}{ }^{+} 0.5-<0.9 \mathrm{PO}_{4}{ }^{-} 0.025-<0.5$ 圈 $\mathrm{BOD}_{5}>15 \mathrm{NH}_{4}{ }^{+}>0.9 \mathrm{PO}_{4}>0.5 \square$ indefinite

Fig. 3. Ecological preferences of benthic diatoms in the studied streams in relation to : a) conductivity ; b) $\mathrm{pH}$; c) organic pollution and eutrophication.

Fig 3. Préférences écologiques des diatomées benthiques en fonction de : a) conductivité ; b) pH ; c) pollution organique et eutrophisation. 

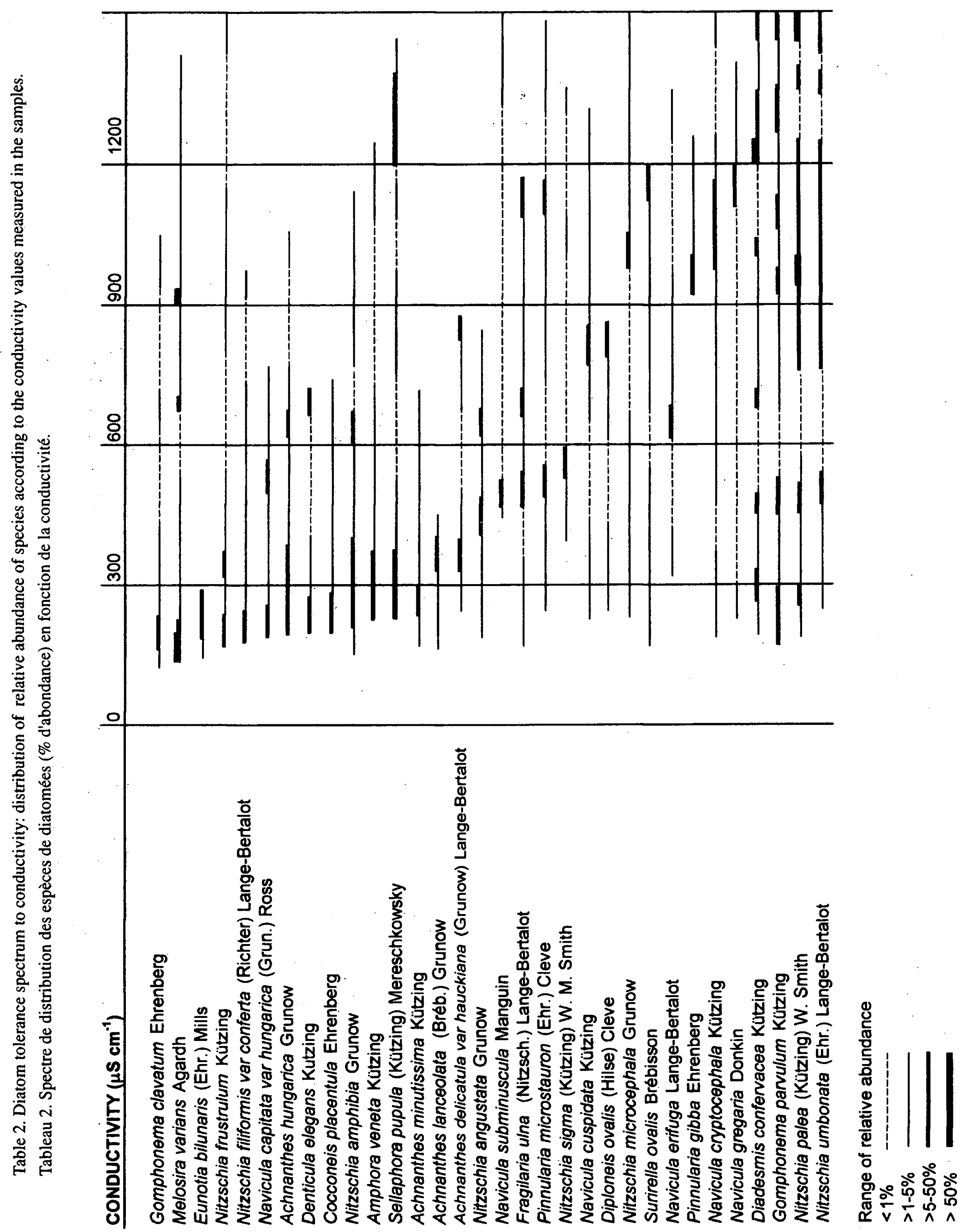


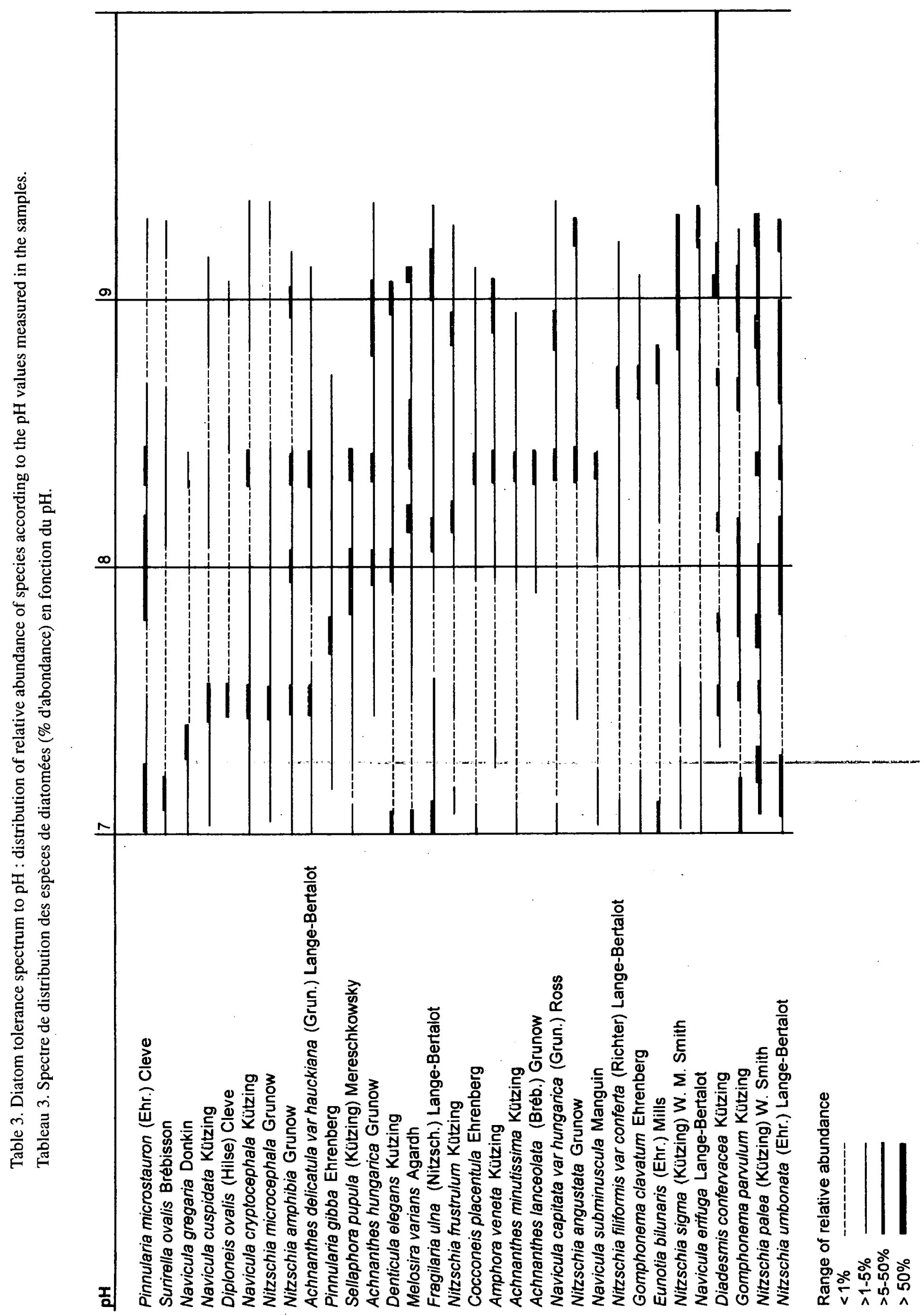



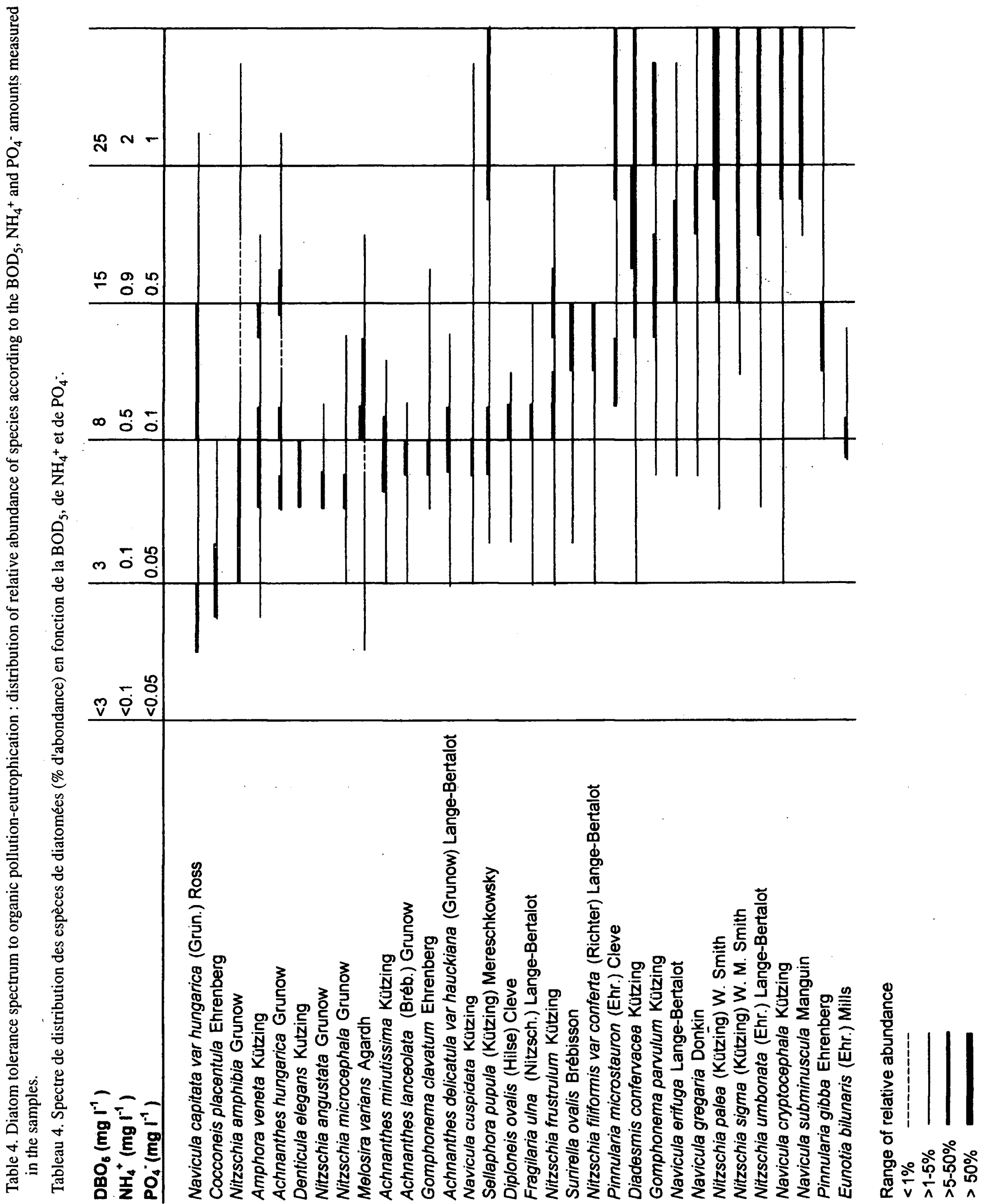
nanthes hungarica, Denticula elegans, Melosira varians, Gomphonema clavatum, Nitzschia frustulum and $N$. filiformis were negatively related with conductivity while Nitzschia palea and $N$. umbonata were positively related. Although some of them showed a wide tolerance range to the salt amount in the environment, their optimum growth was reached in determined ranges of conductivity eg. Nitzchia palea, N. umbonata, Melosira varians (Table 2).

In relation with $\mathrm{pH}$ spectrum (Table 3 ) species did not show a defined preference in the established ranges (47\% indifferent species) (Fig. 3b). This fact was supported by the absence of significant correlation with this variable.

The organic pollution and eutrophication spectrum showed that more than $50 \%$ of species had their preference range in sites with moderate organic matter and nutrient amount (Table 4). The $31 \%$ of the taxa had their optimum in sites rich in organic matter and nutrients (Fig. 3c). Cocconeis placentula, Gomphonema clavatum, Nitzschia amphibia, N. palea, N. umbonata and Navicula cryptocephala showed significant R ( $<<0.05)$. Some species like Nitzschia angustata, Melosira varians, Fragilaria ulna and $N$. filiformis obtained r (-) with $\mathrm{NH}_{4}^{+}$, while Gomphonema parvulum and Nitzschia umbonata obtained $\mathrm{r}(+)$ with $\mathrm{p}<0.05$.

\section{Discussion}

The hydrochemical composition of the streams analysed was determined by the nature of the substrate, the discharges, and point of diffuse source of pollution. The small streams analysed present filtration and evaporation as predominant processes (Sala et al 1983, Hernández \& González 1993). According to Giménez et al.(1992) the soils in the study area have high sodium quantities and the phreatic water is sodic bicarbonated. Moreover, the pollution leads to marked changes in the composition of major elements mainly in industrial zones (Descy \& Empain 1984). In our study the $\mathrm{Na}^{+}$amount in El Gato stream and Rodríguez stream doubled the concentration measured in El Pescado stream. The latter is subject to a lower level of human-impact (Rodrigues Capítulo 1999).

According to the information obtained from spectrums and following the established ranges the species show defined preferences for organic pollution-eutrophication amount. Whilst for conductivity and, particularly, hydrogen ions amount the species show responses less consistent, possibly because of the narrow range of values measured in the streams.
According to the environmental definitions of autoecological classification systems for algae (Stevenson \& Bahls 1999) the diatomological flora found is oligohalobic (subclass halophilous), which includes freshwater algae with their optimum growth in freshwaterstimulated by some salt. In relation with $\mathrm{pH}$ spectrum the diatoms studied are mainly alkaliphilic. The benthic diatoms found respond to eutrophic environments with moderate to high organic pollution according to Gómez \& Licursi (2001).

The results obtained and the extension of new information coming from other running waters will allow to generate a baseline to improve the spectrums, specially for $\mathrm{pH}$ and conductivity and will provide a valuable tool for the identification of indicator species in epipelic assemblages and for the environmental assessments of running-water from the Pampean area.

\section{Aknowledgments}

The financial support for this study has been provided by the Pict's 01-00000-01812 FONCYT and PIP 4740 CONICET. The authors are indebted to Carlos Roldán, who assisted in the field and Jorge Donadelli for his work in chemical analysis. We also thank to Dr. Sergi Sabater for his comments about this study and the anonymous reviewers for improvements in this manuscript.

Contribution number : 710 .

\section{References}

Anderson E.L., Welch E.B., Jacoby J.M., Schimek G.M. \& Horner R.R. 1999. - Periphyton removal related to phosphorus and grazer biomass level. Freshwat. Biol., $41: 633-651$.

APHA 1998. - Standard Methods for the Examination of Water and Wastewater. American Public Health Association, Washington : $113 \mathrm{p}$.

Cox E.J. 1996. - Identification of Freshwater Diatoms from Live Material. Chapman \& Hall, Oxford : 158 p.

Descy J.-P. \& Empain A. 1984. - Meuse (pp :1-21). In Whitton B.A. (ed.) Ecology of European Rivers. Blackwell Scientific Publications, Oxford : $644 \mathrm{p}$.

Descy J.-P. \& Coste M. 1990. - Utilisation des diatomées benthiques pour l'évaluation de la qualité des eaux courantes. Rapport Final, EC contract B-71-23:64 p.

Depetris P.J. 1995. - Los sedimentos fluviales y lacustres : Granulometría y contenido de materia orgánica. In : Lopretto E.C. \& Tell G. (eds). Ecosistemas de Aguas Continentales. Metodologİas para su estudio (Tomo I). Ediciones Sur. La Plata : 377 p.

Forrester G.E., Dudley T.L. \& Grimm N.B. 1999. - Trophic interactions in open systems : Effects of predators and nutrients on stream food chains. Limnol. Oceanogr., 44 : 1187-1197.

Gasse F. 1986. - East African diatoms : Taxonomy, ecological distribution. Bibliotheca Diatomologica, Band 11. J. Cramer (ed.) Berlin, Stuttgart : 203 p.

Giménez J.E., Hurtado M.A., Cabral M.G. \& Da Silva M.M. 1992. - Estudio de suelos del partido de La Plata. Etapa I. Sector Oeste-Noroeste. Informe Final : 189 p.

Gómez N. 1998. - Use of epipelic diatoms for evaluation of water quality in the Matanza-Riachuelo (Argentina), a Pampean plain river. Wat. Res., 32(7) : 2029-2034. 
Gómez N. 1999. - Epipelic diatom from the Matanza-Riachuelo river (Argentina), a highly polluted basin from the Pampean plain : biotic indices and multivariate analysis. Aquatic Ecosystem Health and Management, 2 : 301-309.

Gómez N. \& Licursi M. 2001. The Pampean Diatom Index (Idp) for assessment of rivers and streams in Argentina: Aquatic Ecology, $35: 173-181$.

Hernández M.A. \& González N. 1993. — Recursos Hídricos y Ambiente. In : F. Goin \& R. Goñi (eds) Elementos de política ambiental. Di Giovanni, La Plata, Argentina : 938 p.

Hustedt F. 1930. - Bacillariophyta (Diatomeae) In :Die Susswasserflora Mitteleuropa, Vol 10. Pascher A. (ed.). Jena : 465 p.

Krammer K. \& Lange-Bertalot H. 1986. - Süsswasserflora von Mitteleuropa, Bacillariophyceae 1: Naviculaceae. Gustav Fischer Verlag, Stuttgart : $876 \mathrm{p}$.

Krammer K. \& Lange-Bertalot H. 1988. - Süsswasserflora von Mitteleuropa, Bacillariophyceae 2 : Bacillariaceae, Epthemiaceae, Surirellaceae. Gustav Fischer Verlag, Stuttgart : 596 p.

Krammer K. \& Lange-Bertalot H. 1991a. - Süsswasserflora von Mitteleuropa, Bacillariophyceae 3 : Centrales, Fragilariaceae, Eunotiaceae. Gustav Fischer Verlag, Stuttgart : $576 \mathrm{p}$.

Krammer K. \& Lange-Bertalot H. 1991b. - Süsswasserflora von Mitteleuropa, Bacillariophyceae 4 : Achnanthaceae, Literaturverzeichnis. Gustav Fischer Verlag, Stuttgart : 437 p.

Krno I., Sporka F., Bulánková E., Tirjaková E., Illyová M., Stefková M., Tomajka J., Halgos J., Bitusik P., Illésová. \& Lukás J. 1998. - The influence of organic inputs, acidification and fluctuating discharge on a spring ecosystem. In Advances in River Bottom Ecology, G. Bretschko \& J. Helesic (eds), Backhuys Publishers, Leiden, The Netherlands : 99-106.

Lange-Bertalot H., 1979. - Pollution Tolerance of Diatoms as a Criterion for Water Quality Estimation. Nova Hedwigia, 64 : 285-304.

Lowe R.L., 1974. - Environmental Requirements and Pollution Tolerance of Freshwater Diatoms. US Environmental Protection Agency, EPA-670/4-74-005. Cincinnati, Ohio, USA : 333 p.

Lowe R. \& Laliberte G.D. 1996. - Benthic stream algae : distribution and structure. Hauer, R. \& Lamberti GA (eds). In : Stream Ecology. Academic Press, London : 669 p.

Mackereth F.J.H., Heron J. \& Talling J.F. 1978. — Water Analysis : Some revised methods for limnologists. Freshwater Biological Association, Scient. Publi. $\mathrm{N}^{\circ} 36: 120 \mathrm{p}$.

Maucha R. 1932. - Hydrochemische Methoden in der Limnologie. Die Binnengewässer, $12: 1-173$.

Pan Y., Stevenson R.J., Vaithiyanathan P., Slate J. \& Richardson Curtis J. 2000. - Changes in algal assemblages along observed and experimental phosphorus gradients in a subtropical wetland, U.S.A. Freshwat. Biol., $44: 339-353$.

Patrick R. \& Reimer C.W. 1966. - The Diatoms of the United States, exclusive of Alaska \& Hawaii. Academy of Natural Sciences. Philadelphia, Vol I : 668 p.

Patrick R. \& Reimer C.W. 1975. - The Diatoms of the United States, exclusive of Alaska \& Hawaii. Academy of Natural Sciences. Philadelphia, Vol. II. : 213 p.
Rodrigues Capítulo A. 1999. - Los macroinvertebrados como indicadores de la calidad de ambientes lóticos en el-área Pampeana. Rev. Soc. Entomol. Argent., 58 : 208-217.

Sabater S. \& Sabater F. 1988. - Diatom assemblages in the River Ter. Arch. Hydrobiol., $111: 397-408$.

Sabater S. \& Roca J.R. 1990. — Some factors affecting distribution of diatom assemblages in Pyrenean springs. Freshwat. Biol., 24 : 493-507.

Sala J.M., Gonzáles N. \& Kruse E.E. 1983. - Generalización hidrológica de la provincia de Buenos Aires, pp. 975-1009. In : Coloquio Internacional sobre hidrologia de grandes llanuras. J. Prego (ed.) Olavarría. Argentina.

Schoeman F.R. 1976. - Diatom indicator groups in the assessment of water quality in the Juskei-Crocodile River system (Transvaal, Republic of South Africa). Journal of the Limnological Society of Southern Africa, 2 : 21-24.

Sokal R.R. \& Rohlf F.J. 1969. - Biometría. Principios y métodos estadísticos en la investigación biológica. H. Blume (ed.) Madrid : $832 \mathrm{p}$.

Steinberg C. \& Schiefele S. 1988. - Biological Indication of Trophy and Pollution of Running Waters. Z. Wasser-AbwasserForsch., 21 : 227-234.

Steinberg C. \& Putz R. 1991. - Epilithic diatoms bioindicators of stream acidification. Verh. Int. Ver. Limnol., 24 : 1877-1880.

Stevenson R.J. 1984. - Epilithic and epipelic diatoms in the Sandusky River, with emphasis on species diversity and water pollution. Hydrobiologia, 114 : 114-161.

Stevenson R.J. \& Bahls L.L. 1999. - Periphyton Protocols. In : EPA Rapid Bioassessment Protocols for Use in Wadeable Streams and Rivers. Periphyton, Benthic Macroinvertebrates and Fish. Second Ed., Washington : $326 \mathrm{p}$.

Stevenson R.J. \& Pan Y. 1999. - Assessing environmental conditions in rivers and streams with diatoms, pp. 12-40 In : The Diatoms : Applications for the Environmental and Earth Sciences. E.F. Stoermer \& J.P. Smol (eds), Cambridge University Press : $469 \mathrm{p}$.

Tabatabai M.A. 1974. - Determination of Sulfate in Water Samples. - The Sulfur Institute Journal, Vol. 10, (2) : 10-18.

Tangorra M., Mercado L., Rodrígues Capítulo A. \& Gómez N. 1998. - Evaluación de la calidad ecológica del $\mathrm{A}^{\circ} \mathrm{El}$ Gato a partir del estudio del bentos, fitoplancton y variables físico-químicas. Anal. Congr. Nac. del Agua., 5 : 212-220.

Van Dam H., Mertiens A. \& Sinkeldam J. 1994. - A coded checklist and ecological indicator values of freshwater diatoms from the Netherlands. Neth. J. Aquat. Ecol., 28 : 117-133.

Wilderman C.C. 1984. - Techniques and results of an Investigation into the autoecology of some major species of diatoms from the Severn River Estuary, Chesapeake Bay, Maryland, U.S.A. In Proceedings of $8^{\text {th }}$ International Diatom Symposium. M. Ricard (ed.) Koeltz Scientific Books : 631-643. 